\title{
C-X-C Motif Chemokine 6
}

National Cancer Institute

\section{Source}

National Cancer Institute. C-X-C Motif Chemokine 6. NCI Thesaurus. Code C29339.

C-X-C motif chemokine 6 (114 aa, $\sim 12 \mathrm{kDa}$ ) is encoded by the human CXCL6 gene. This protein is involved in neutrophil chemotaxis, angiogenesis and anti-bacterial activity. 